Canadian University Music Review

Canadian University Music Review

Revue de musique des universités canadiennes

\title{
A Sociological View of Music Education: An Essay in the Sociology of Knowledge
}

\section{Graham Vulliamy}

Numéro 5, 1984

URI : https://id.erudit.org/iderudit/1013929ar

DOI : https://doi.org/10.7202/1013929ar

Aller au sommaire du numéro

Éditeur(s)

Canadian University Music Society / Société de musique des universités canadiennes

ISSN

0710-0353 (imprimé)

2291-2436 (numérique)

Découvrir la revue

Citer cet article

Vulliamy, G. (1984). A Sociological View of Music Education: An Essay in the Sociology of Knowledge. Canadian University Music Review / Revue de musique des universités canadiennes, (5), 17-37. https://doi.org/10.7202/1013929ar

All Rights Reserved (C Canadian University Music Society / Société de musique des universités canadiennes, 1984
Ce document est protégé par la loi sur le droit d'auteur. L’utilisation des services d'Érudit (y compris la reproduction) est assujettie à sa politique d'utilisation que vous pouvez consulter en ligne.

https://apropos.erudit.org/fr/usagers/politique-dutilisation/ 


\title{
A SOCIOLOGICAL VIEW OF MUSIC EDUCATION: AN ESSAY IN THE SOCIOLOGY OF KNOWLEDGE
}

\author{
Graham Vulliamy
}

In 1982 Keith Swanwick, Professor of Music Education at the University of London Institute of Education, delivered a paper to the 15th International Society for Music Education Conference. Its theme was a consideration of my own work over the previous decade as a "case study which illuminates several problems in music education" (Swanwick 1982: [1]). It is certainly reassuring to find such an interest in sociological work from an outsider to this discipline-the more so when sociology itself is increasingly coming under attack. In the recent government cuts inflicted upon tertiary education in Britain, it is the social sciences that were earmarked for especially harsh treatment. Sir Keith Joseph made his own views explicit when, as Secretary of State for Education and Science, he requested that the word "science" be deleted from the title of the Social Science Research Council. While many sociologists, myself included, are unhappy about some of the connotations of science for our discipline, such reservations are rather different from the more sinister motives implied by Sir Keith. Perhaps the only redeeming feature of this otherwise ludicrous affair was the variety of humorous parodies that ensued, with Professor Laurie Taylor concluding in his Times Higher Education Supplement column that the research council's problems could be solved by labelling it the Social Marmalade Research Council (see Taylor 1983). In such a climate the attention given by Swanwick to a sociological perspective on music education is to be welcomed, even when, after conceding certain parts of my argument, he proceeds to isolate what he believes are "three crucial misconceptions" in the thesis, culminating in certain 
aims which he argues are both "anti-educational" and "practically impossible to carry forward in schools."

This paper, like Swanwick's, could also be described as a case study of my own work and the particular sociological approach to music education that it has adopted. Not surprisingly, however, its focus will be very different from that of Swanwick's. His analysis concentrated upon both the musical assumptions underpinning my thesis and its practical implications for music teaching, while I will be concerned with its sociological aspects. Nor will there be any attempt here to provide a response to Swanwick. The issues he raises are both important and complex, but given that they are prefaced on a considerable misunderstanding of sociological arguments advanced by both John Shepherd (see Shepherd 1977) and myself and also, we would argue, of aesthetic considerations pertaining to the essence of music, we have addressed his criticisms in detail elsewhere (see Vulliamy \& Shepherd 1984).

In a sense my paper is an essay in the sociology of knowledge. It will show how a particular sociological approach to music education emerged and developed in Britain as a direct response to both shifting concerns in the sociology of education and to special biographical factors. In focussing upon sociological, as opposed to musical, criticisms of my work, I will highlight the circumscribed nature of the issues it has raised. For example, having been located in a sociology of education paradigm, rather than in mainstream sociology, British work has neglected many of those features which have constituted research in this area in other countries. While providing, therefore, what is hopefully a useful survey of one particular sociological view of music education, this paper should also demonstrate the profound ways in which our knowledge has been restricted by disciplinary, institutional, and biographical factors.

The origins of my work are located in what is still rather misleadingly referred to as the "new sociology of education," a radical departure in sociological thinking on education whose advent was signalled in 1971 by the publication of the influential volume Knowledge and Control: New Directions for the Sociology of Education (Young 1971). The impact of this book, together with the adoption of its approach in the Open University's first Sociology of Education course School and Society (E282), was such that it was heralded as creating a Kuhnian paradigm shift in the sociology of education (see Gorbutt 1972). This begs 
a number of questions related both to the over-simplicity of the "new sociology of education" label itself and to whether Kuhn's (1962) analysis of science can validly be applied in this case. However, notwithstanding such reservations, it certainly was the case that the early 1970 s witnessed a marked change of emphasis in sociological perspectives on education.

I will now highlight three dimensions of such a change. First, there was an application of the sociology of knowledge to the school curriculum. Traditional approaches to the sociology of education in Britain had viewed the school curriculum as relatively unproblematic, whereas the new sociology of education incorporated a critical analysis of what counts as educational knowledge (see Whitty \& Young 1976). Secondly, the adoption of symbolic interactionist and phenomenological approaches led to a focus upon classroom interaction and school processes-a marked change in both theory and methodology from the survey analysis characterizing much previous work (see Hammersley \& Woods 1976). Thirdly, a combination of this phenomenological approach and a reference to anthropological studies led to a questioning of commonly accepted educational categories, such as ability (see Beck et al. 1976).

The upshot of these new approaches was to question more traditional explanations of school failure, which had emphasized the deficient home background of those who failed, and to focus instead on the social nature of what they failed at. Thus theories of linguistic and cultural deprivation underpinning compensatory education programs were denounced as myths (see Keddie 1973), and instead both the curricula and the processes of schooling were held responsible for helping reproduce the social and cultural hegemony of the middle classes.

As a graduate student under the supervision of Michael Young, shortly after the publication of his book (1971), I began to look critically at the school curriculum; moreover, my background as a jazz and rock musician led me to believe that the new sociology of education provided a potentially useful way of viewing current features of both music teaching and education more generally. This began with a number of brief observations:

1. I had known many highly talented musicians who had nevertheless been defined as musically inept at school.

2. The problem seemed to lie with the school curriculumschool students were certainly very interested in music, but not school music. 
3. There appeared to be a cultural clash between school music and the styles of music students were involved in. Young's (1971: 31-41) concept of the "stratification of knowledge" could be used to analyze the rigid distinction between subject-based high status knowledge ("serious" music) and everyday low status knowledge ("pop" music).

4. The musical culture of the students was seen as a "deprived" one, but it was clear to me that both "classical" musicians and teachers viewed this culture in a totally distorted and ideological way.

A detailed examination was then made of the "subject perspective" (Esland 1971) of music teachers, by an analysis of both current texts on music teaching and historical accounts of the development of music as a school subject. Critical historians of education (such as Johnson 1976) have argued that the growth of mass schooling was motivated primarily by a need to reform and incorporate working-class cultures into the mainstream culture, rather than by any need to provide new skills. Industrialization during the last century resulted in a process of de-skilling, with craft skills giving way to factory unskilled work, but what was required was a new docile and moral factory labor force. The earliest introduction of singing into schools as a compulsory activity can be usefully viewed in this light. The pioneers of school music teaching in Britain stressed the beneficial religious and moral influence of singing. John Turner, for example, noted that a more general diffusion of vocal music would "contribute largely to the rooting out of dissolute and debasing habits" given the "partially subconscious effect of these frequently repeated maxims and moral ditties which formed the text of the songs concerned" (quoted in Rainbow 1967: 157).

Since then the scope of school music teaching has widened enormously (see Vulliamy 1977b: 203-06). The most influential developments have been the music appreciation movement of the 1920s and 1930s, which established music as a classroom subject with its own syllabus and examinations; the enormous growth in instrumental tuition, especially in extra-curricular activities; and the challenge of the "creative" music educators. The latter approach, associated with the work of John Paynter and the Schools Council "Music in the Secondary School Curriculum" Project (see Paynter 1983), has played down the emphasis upon traditional "classical" music and notation and 
developed the use of techniques that contemporary avant-garde composers use. It has also stressed the importance of the active exploration of sounds by all students as a part of their general education.

Given these aspects of the subject perspective of music teachers, what I found interesting, given my own particular musical interests and capabilities, was the total absence of any consideration of Afro-American music. A product of the fusion of two great musical cultures-the African and the European -black music, via its mainstream of blues on the one hand and gospel/spirituals on the other, has been the major influence on popular music throughout this century. The music critic Henry Pleasants, in his stimulating book Serious Music and all that Jazz (1969), argues that the Afro-American musical revolution will undoubtedly be seen by future historians as the most significant musical revolution of the twentieth century in that it has provided the backbone to styles of music that now have enormous international appeal.

This prompted me to look back at historical records to see how and why it was that the music establishment came to react so violently against this new musical revolution that it almost came to the point of viewing it as not music at alland certainly not music worthy of encouragement in education (see Vulliamy 1976: 20-22). There appear to be two main reasons. First, the music was resisted because of its identification with black people, a low status group in society, and because of further identifications with crime, vice, and greater sexual freedom. Secondly, traditionally trained "classical" musicians opposed the new music because it seemed to violate both "classical" musical standards (with blue notes, impure tones, and so on) and "classical" cultural standards (being played in neither concert halls nor churches). Rock'n roll in the mid 1950s, and later developments of rock music, were generally greeted with a similar moral outrage by members of the musical establishment.

Such reactions led to a central tenet of the subject perspective of music teachers being an assumed dichotomy between "serious" music and "popular" music, where all varieties of Afro-American music are grouped under the latter label. This dichotomy could be usefully situated in an analysis of high culture critiques of mass culture (see Vulliamy 1977a), with the legitimacy of different cultural forms being a response to the kinds of socio- 
logical influences stressed by the French sociologist Pierre Bourdieu. He argues that dominant groups in a society are in a position to impose their social constructions or meanings (concerning cultural values, the production of art works, and so on) on others in a form of what he calls "violence symbolique" (see ibid.: 192). The result has been the prevalent establishment ideology concerning the nature of "pop" music. This ideology can be characterized by four separate, although interrelated, assumptions:

1. Pop music is a homogeneous product.

2. Pop music's sole motivation is a commercial one.

3. The musical tastes and emotions of young people are thus manipulated by commercial exploiters who aim their product at a mass market.

4. Afro-American and other oral musical styles can be evaluated using the musical criteria of traditional "classical" music.

Each of these assumptions is, as I have argued at length elsewhere (see Vulliamy 1975: 20-22; 1980a: 40-46; 1980b: 59-60), fundamentally misconceived and the educational system and the mass media are two of the most important institutions helping promulgate this establishment ideology.

Young had written in his introduction to Knowledge and Control that we have very few studies of "how contemporary definitions of culture have consequences for the organization of knowledge in the school system" (1971: 10). This, together with Keddie's (1971) chapter "Classroom Knowledge" in the same book, which looked at the social assumptions underpinning teachers' definitions of knowledge and ability in the context of interaction in the classroom, prompted me to carry out a similar participant observation study in a school music department (see Vulliamy 1977b: 208-21).

I deliberately chose a school with a music department which had a high reputation, and particularly for the wide variety of musical styles encouraged (including dance bands, military bands, choirs, and orchestras). This wide variety, and most notably the dance band which played jazz/swing styles of music, was extremely successful in motivating large numbers of students to play musical instruments. It is worth noting briefly here that, unlike in North America, such school dance bands were extremely rare in Britain a decade ago, as they 
still are, although less so, today. I found that the potential variety of musical styles was accommodated within the more traditional legitimate concerns of music teaching. Thus the main emphasis of the music department was to produce good all-round instrumentalists with a thorough grounding in the "discipline" of music. This definition of "what counts as music" (backed up by classroom music lessons on musical notation, history and appreciation, and traditional music theory) both made music approximate to other academic disciplines and excluded any style of music (such as rock or pop) that did not fit these criteria. It was perhaps not surprising, therefore, that I found that the music teachers should assume that those students (in the upper streams) who were good at other academic subjects might also be good at the discipline of music, while those students who had failed in other academic subjects would also fail at music. To succeed in classroom music, just as in Keddie's (1971) study, required that students took over the teachers' definition of the situation (or at least pretend that they did), which involved, amongst other things, an acceptance of the dichotomy between "serious" and "popular" music with all its false assumptions.

A comparison with different approaches to music teaching, including that of the recent "creative" music educators, suggested that there was a clear association between "what counts as music" and different criteria of success, different relationships between teacher and taught and different teachers' perceptions relating to intelligence, family background, and musical ability. This was especially marked in the case of what I called "open" music teaching, where examples were given from both a technical college (see Vulliamy 1976: 27-28) and a comprehensive school (see Vulliamy 1977b: 224-26; see also Nicholls 1980). These approaches started with the musical interests of the students, with no attempt to "sell" any particular style of music by the teacher. They resulted in a very large variety of musical styles (classical, avant-garde, jazz, folk, rock, pop). Authority relationships between teacher and student were broken down and, most significantly, criteria of success changed in such a way that many of the departments' acknowledged best musicians could not read a note of music.

I therefore concluded the account of my participant observation study by arguing that the widely publicized problems that school music teachers have with teenage students might be better explained in terms of the teachers' definitions 
of music rather than in terms of the supposed deficiencies of students. This confirms one of the basic insights of the new sociology of education-namely that prevailing conceptions of educational knowledge play a significant role in maintaining traditional patterns of educational success and failure (see Vulliamy 1977b: 226-27).

From its inception the new sociology of education was subjected to a number of strident criticisms and after 1976, following the interest created in Britain by the publication of Bowles's and Gintis's book Schooling in Capitalist America (1976), sociological accounts of schooling became increasingly dominated by neo-Marxist perspectives on the hidden curriculum, on the relationships between schooling and the economic structure, and on the role of the State. Since my work on the sociology of music education had been used in the Open University Schooling and Society course (E202) as an example of the new sociology of education (see Whitty 1976), I felt that such criticisms needed to be taken on board.

Philosophers such as Pring (1972) and Flew (1976) argued that Young's (1971) application of a sociology of knowledge perspective to educational knowledge is in places highly suspect epistemologically in its celebration of what is seen as an extreme form of relativism. In the absence of alternative truth criteria for alternative knowledge structures, philosophers can persuasively argue that high status knowledge is as it is simply because it is better. The corresponding viewpoint in music education, and one very widely held, is that our emphasis on "classical" music reflects the fact that such music is better and more highly developed than other styles of music, like jazz or pop, coexisting in our society. Such a view is supported by the work of musicologists and music aestheticians such as Meyer (1956; 1959; 1973) and Langer (1960). Their explanation into the meaning of music leads to their holding an objectively conceived aesthetic whereby the meaning of music and its relative worth can be related to certain objective features. In countering such a view, I drew upon the work of Shepherd (1977) who argues that current theories of music aesthetics are inadequate in that they fail to recognize the inherently social nature of all music (see Vulliamy 1978: 116-18). He concludes that different musical languages are culture-specific to the societies from which they emerge and that therefore different musical languages require different criteria of evaluation. A valid social theory of 
music must be based on an acceptance of the relativity of aesthetic judgement across different musical traditions.

A second major criticism of the new sociology of education was that phenomenologically based participant observation studies, such as that by Keddie (1971), were ahistorical and put too much emphasis on the ability of participants actively to construct or change their realities (see Sharp \& Green 1975: 15-35). Where the focus is on teachers, this can lead to an over-simplistic "blame the teacher" view. However, I argued that this quite valid criticism can be met by building in an historical approach that attempts to locate current attitudes as part of an ongoing historical process (see Vulliamy 1978: 119). Thus the report of my participant observation research was prefaced by a section on the historical background to the "subject perspective" of music teachers. Given this, a "blame the teacher" view is indeed naive because teachers are unwittingly constrained by the legacy of a dominant ideology, concerning the relationships between music and culture, which goes back to the very origins of music teaching.

This brings me to a third, and in my view the most powerful, criticism of the new sociology of education-that it was overoptimistic about the possibilities of radical educational change and that it lacked an adequate theory as to how such change could be brought about (see Whitty 1974). As Bowles and Gintis (1976) argue, supposedly progressive educational reforms tend to be incorporated into the present structures of schooling and thus lose their radical sting. Recent developments in music teaching illustrate this well. There is no doubt that over the last few years varieties of pop, rock, and ethnic musical styles have increasingly been used by some teachers (see Vulliamy \& Lee 1982b). However, this has usually been done in such a way as to offer no real challenge to the existing stratification of knowledge or to the dominant musical establishment. Such points have been developed in a recent article, jointly written with John Shepherd (see Shepherd \& Vulliamy 1983). The influence of recent scholarship in the sociology of music on the sociology of music education leads to an extension of earlier arguments. Thus we suggest that the processes of school music teaching contribute not only to the legitimation of a dominant musical ideology but also, more speculatively, to much more pervasive ideological assumptions underpinning capitalist societies. Despite music's generally marginal status on the 
school curriculum as compared with high status academic knowledge, we contend that the contribution that it makes to the reproduction of capitalist ideology is significantly greater than this marginal status suggests.

Such conclusions arise from a comparison of school music teaching in England and Ontario. In a participant observation study designed to replicate my own work, Shepherd (1983) found that, unlike in England, no overt culture clash was found in Ontario schools between "school" music and "students"" music. This was for two main reasons. First, music curricula in North America tend to be based largely on big band, dance band, show, and light classical music. While this music has enough in common with the criteria of "what counts as good music" to satisfy parents and school boards on the one hand, it frequently alludes sufficiently to the inflectional, improvisatory, and timbral qualities of the students' own musical subcultures on the other to mollify, although not eradicate, possible opposition to classroom music. Secondly, unlike in most English schools, music is not a compulsory subject in Canada. However, by focussing upon the deep structure of the pedagogical process, as opposed to surface features of classroom interaction, we argue that despite the differences in social context between Ontario and England, particular ideologies of the dominant musical culture are transmitted in very similar ways. What is shared is a conception of music as equatable with musical notation. This is illustrated by a number of classroom examples in which a notational filter is used by the teacher to defuse the essential Afro-American musical characteristics of pop and rock music when students are either playing or listening to such music in the classroom (see Shepherd \& Vulliamy 1983: 7-8). Notation has also proved a major constraint on attempts to reform school music teaching in England. Some teachers have recognized that the growing use of pop and rock music exclusively with less able students does nothing to challenge the existing stratification of knowledge or the dominant musical ideology. But attempts to incorporate Afro-American music into the higher status examinable sections of music teaching have resulted in examination boards insisting that musical notation must be covered in such work (ibid.: 9).

Drawing upon both the work of Wishart (1977) and Shepherd (1982), we argue that this notated conception of music has a much more deep-seated ideological significance than might at 
first be apparent. The bare outline of the argument is as follows. Music is inherently socially significant and different musical languages differentially encode and articulate various social realities. At one extreme, the dominance of a functional-tonal musical framework, together with a notated conception of music, is expressive of a society with both a rigid hierarchy in terms of authority structure and with an epistemological divide between body and mind, subjective and objective, mental and physical, and so on. At the other extreme, different styles of popular music articulate a potential challenge to industrial, capitalist ideology, through both the different relationship of sounds to the functional-tonal musical framework and, in extreme cases such as free jazz and some progressive rock, through an attempt to abandon the framework totally. Therefore, when the radical potential of an oral-aural musical language is defused in the classroom by a notational filter derived from functional-tonality, the students are not only socialized into a dominant musical ideology, but they are also socialized into fundamental epistemological assumptions underpinning industrial, capitalist society (see Shepherd \& Vulliamy 1983: 10). Thus we would concur with the following assessment made by Davies in his survey of the significance for schooling of certain aspects of popular and working-class culture:

When the school recognizes the existence of, for example, popular music, dance and style (as it sometimes is forced to do), it relegates these to the periphery of school life (lunch-time discos) or characterises them as merely shallow and transient. School culture does not penetrate the subjective experiences of its pupils as a "whole way of life." It does not validate the symbolic and expressive forms through which subjectivity and "self" are defined and lived out by contemporary youth. More often that not, it anathematizes them (1981: 85).

This summary of my approach to a sociology of music education, although brief, should nevertheless be a sufficient basis from which to make a number of general observations. Moreover, the absence of any other published work on the sociology of music education in Britain enables us to make some generalizations as to how and why research on this theme has differed from that in other countries.

First, the impetus for such work was originally derived from the sociology of education, rather than from either music 
education or music, or, indeed from mainstream sociology itself, and its scope has shifted according to changing intellectual fashions in the sociology of education. These shifting fashions have been closely parallelled by those in other sub-disciplines of sociology. For example, the development of the sociology of medicine over the last two decades has been a response to very similar influences. In the 1950s and 1960s the dominance of a structural-functionalist perspective meant that the concept of health itself was rarely made problematic (consider, for example, the notion of the "sick role" in Parsons [1951]), just as in the traditional sociology of education the concept of education was seldom questioned. However, in the same year as the publication of Young's Knowledge and Control (1971), Dreitzel was arguing that "there is no 'objective' definition of illness; instead it is necessary to ask in whose interest and with what purpose in mind illness is socially defined by different people" (1971: vi). As with the new sociology of education, this was followed by a range of studies from both interactionist and phenomenological perspectives. What counts as health was relativized and interest shifted from macro issues to micro studies of the processes of doctor-patient interaction (see Dingwall 1976; Wadsworth \& Robinson 1976). The critique of the new sociology of education implied in Bowles's and Gintis's neo-Marxist perspective was also mirrored by Navarro's (1976) analysis of the way in which health care systems help reproduce the economic and social bases of a capitalist society. Much ensuing research in both the sociology of education and the sociology of medicine can be seen as exhibiting a lively tension between the phenomenological and structural poles of a continuum on which sociologists have critically analyzed the role of educational and health care systems in capitalist society (for education, see the units and course readers for the Open University Society, Education and the State [E353] course [1981]; for health, see Stacey et al. 1977; Dingwall et al. 1977; Doyal \& Pennell 1979).

Without having conducted similar such analyses, I nevertheless suspect that many sub-disciplines of sociology have shown a parallel drift in intellectual concerns. By accommodating itself to such a drift, the sociology of music education in Britain has therefore to some extent kept in touch with mainstream sociology. However, its location within the sociology of education has clearly been limiting in important ways. The focus has been upon the ways in which the teaching of music has exem- 
plified, or even contributed to, the reproduction of social class relations in capitalist society through both its overt and hidden curricula. As such there tends to have been a concentration on social class at the expense of other variables such as age, sex/ gender, and race/ethnicity. Each of these will now briefly be considered in turn, together with their possible implications for a sociology of music education.

Marxist approaches to the sociology of youth cultures, associated particularly with the work of the Birmingham Centre for Contemporary Cultural Studies (see Hall \& Jefferson 1976), have challenged conventional approaches and made a plea that social class should be reinstated as a crucial factor in the sociology of youth. Such arguments are now largely taken for granted in contemporary surveys of the field. Thus, for example, Brake asserts that:

What is central to any examination of youth culture is that it is not some vague cultural monolith appealing to those roughly under thirty, but is a complex kaleidoscope of several subcultures, of different age groups, yet distinctly related to the class position of those in them (1980: vii).

However, as Marsland has recently argued, such analyses are sometimes taken too far to suggest that "youth as a concept is unthinkable" (1982: 154). The focus on social class as the crucial variable permeating styles of youth culture is important, but it is also important to realize that young people in modern industrial society, regardless of class, sex, or ethnicity, tend to be isolated as a dependent, economic liability, and thus experience what Eisenstadt (1956) has referred to as a marginal status in moving from the family in which they are brought up to full membership of the social and economic system in which they must eventually take their place. At school, in college, and on the lowest rungs of the work ladder, they have emerged from one family but have not yet formed another. Consequently, they are not fully integrated into the social system. They are contained in a number of social institutions, where they are encouraged to adopt the attitudes and values of adults, but where they experience little of the power and influence of adults. A neglect of age itself as a significant variable leads Tanner to view "Top 40" pop in Canada as the music of that majority of high school students, who "endorse the assumptions and values which underlie school culture" (1981: 10), while noting that the 
adoption of "heavy metal" music was confined to delinquents and working-class school rejectors. But, as Shepherd has pointed out, it is possible that many high school students embrace the more conventional "Top 40" pop not because they uncritically "endorse the assumptions and values which underlie school culture" but because they "see no great problems with the world in which they live, but . . . nevertheless [experience] temporarily a marginal status vis-à-vis that world" (1982: 164). If "Top 40" pop expressed entirely consensual social values, it would be surprising not to find it included in the school curriculum. That it is not is symptomatic of its incipient values of disaffection.

Analyzing the content of publications in the British sociology of education over the 1960-79 period, Acker (1981) has conclusively demonstrated their neglect of gender issues, although this dearth has to some extent been remedied by a more recent spate of books on the theme of gender and education (see for example, Spender 1982; Stanworth 1983; and Walker \& Barton 1983). Frith and McRobbie (1978/79) have also initiated a debate on the relationship between rock music and sexuality, when they argue that teenagers learn to identify with and internalize adult sex and gender roles through their orientation to different sex-linked styles of rock music. Dominant ideologies of masculinity and femininity are conveyed through the machismo of "cock rock" on the one hand and the romanticism of "teeny bop rock" on the other. The implications of such sociological research on education or socialization through music for a sociology of music education have yet to be explored. Nor have analyses been developed of the commonly observed phenomenon in more traditional school music teaching of sex role stereotyping in students' choices of different instruments of the orchestra.

Issues connected with race and ethnicity have been addressed in the sociology of music education adopted here, but only briefly (see Vulliamy \& Lee 1982a; and Vulliamy 1978: 125). Hebdige's (1979) analysis of the importance of black music and black style in the interrelationships between recent black and white youth cultures in Britain is suggestive. There are British schools, for example, where the positive espousal of a reggae culture by West Indian students has not only permeated other subject areas like English and Craft Technology (via building disco "sound systems"), but has also acted as an ongoing 
critique of deep-seated aspects of the hidden curriculum of schooling.

If a location within a sociology of education paradigm has been one limitation of this sociological view of music education, another equally important one has been the restricted interest in Afro-American and related popular music styles. Such an emphasis is a product of biographical factors-namely my background as a rock musician with no formal training in "classical" music. As a consequence, I have not pursued the kinds of issues addressed by Derrick Wright in what, to my knowledge, is the only other research program in the sociology of music education to have been carried out in Britain (excepting a few unpublished undergraduate and master's dissertations). Funded by the Social Science Research Council (as it was once called!), Wright developed a particular method of analysis to study interaction in primary school music classes. As noted in the conclusion of a theoretical paper on the social determination of musical meaning the research was intended to:

... explicate the taken-for-granted assumptions, the trustworthy recipes, by which meaning is given to a group of sounds .... By looking at the assumptions concerning music which are held by teachers and their pupils, and the way in which these assumptions influence the teaching of music in the classroom, the research investigates the social rules operated by teacher and pupil to classify sounds as music or non-music (Wright 1975: 432).

Wright's analysis is based upon observation and tape recordings of music classes. Transcriptions of the tapes were analyzed by a method derived from three approaches: Goffman's (1975) frame analysis, Sinclair and Coulthard's (1975) discourse analysis, and Wright's (1975) own identification of music as constitutive rules (following both Schutz [1971] and Garfinkel [1967]). The performance of music in the classroom was examined by treating it as sounds contained within a frame, the boundaries of which are marked in some way by frame acts, and discourse analysis was then used to discover the structure of student-teacher exchanges with regard to discourse before and after the performance. In this way Wright argued that the lesson could be "decoded" (Garfinkel 1967: 78) and the assumptions regarding music emerge. A preliminary unpublished paper (Wright n.d.) showed the feasibility of such an endeavor but, following the termination of the research council's funding, 
the research could not proceed to the stage where Wright hoped to compare the implicit musical rules underlying teacher-student interaction in lessons incorporating traditional tonal music and others incorporating more avant-garde creative music making approaches.

A further limitation of the sociological view of music education discussed in this paper is its emphasis on school music teaching, which has led to a neglect of the kinds of "socialization into musicianship" studies (whether rock or classical) to be found in the United States. Nor has there been the collection of empirical data pertaining to both "classical" music and mass media institutions that has characterized the collaboration of sociologists and music educators in MEDIACULT (the International Institute for Audio-visual Communication and Cultural Development) in Europe.

Although my own research interests have shifted toward relevance education in the Third World, following two field research trips to Papua New Guinea since 1979, there are others who hope to plug the kinds of gaps in the British sociology of music education that I have pinpointed in this paper. For example. Georgie Born, a London University doctoral student of anthropology, is planning a comparative analysis of socialization into the traditional criteria of classical music with socialization into the aural-oral musical language of rock, based upon periods of ethnographic study in music academies and schools. Her own background as both a classically-trained musician and a member of the influential avant-garde progressive rock band, Henry Cow, makes her ideally suited to such a task.

My paper is subtitled "An Essay in the Sociology of Knowledge." This is for two reasons. I hope to have shown how it has been the adoption of a sociology of knowledge framework to the school subject of music that has produced a particular view of the sociology of music education in Britain. I have also tried to illustrate a central tenet of the sociology of knowledge itself-namely that bodies of intellectual thought are themselves limited by disciplinary, institutional, and even personal factors. 


\section{REFERENCES}

ACKER, S.

1981: "No-Woman's Land: British Sociology of Education 1960-1979," Sociological Review, XxIX/1, 77-104.

BECK, J. et al., eds.

1976: Worlds Apart: Readings for a Sociology of Education. London: Collier Macmillan.

BOWLES, S. and GINTIS, $\mathrm{H}$.

1976: Schooling in Capitalist America: Educational Reform and the Contradictions of Economic Life. London: Routledge \& Kegan Paul.

BRAKE, M.

1980: The Sociology of Youth Culture and Youth Subcultures. London: Routledge \& Kegan Paul.

DAVIES, D.

1981: Popular Culture, Class and Schooling (Course E353, Unit 9). Milton Keynes: Open University Press.

DINGWALL, R.

1976: Aspects of Illness. London: Martin Robertson.

DINGWALL, R. et al., eds.

1977: Health Care and Health Knowledge. London: Croom Helm. DOYAL, L. and PENNELL, I.

1979: The Political Economy of Health. London: Pluto Press. DREITZEL, H.P., ed.

1971: The Social Organization of Health. London: Macmillan. EISENSTADT, S.N.

1956: From Generation to Generation: Age Groups and Social Structure. New York: Free Press of Glencoe.

ESLAND, G.

1971: "Teaching and Learning as the Organization of Knowledge," in Young, M.F.D., ed., Knowledge and Control: New Directions for the Sociology of Education. London: Collier Macmillan, 70-115.

FLEW, A.

1976: Sociology, Equality and Education: Philosophical Essays in Defence of a Variety of Differences. London: Macmillan.

FRITH, S. and McROBBIE, A.

1978/79: "Rock and Sexuality," Screen Education, No. 29, 3-19. GARFINKEL, $\mathrm{H}$.

1967: Studies in Ethnomusicology. Englewood Cliffs, N.J.: Prentice-Hall.

GOFFMAN, E.

1975: Frame Analysis. Harmondsworth, Middlesex: Penguin Books. 
GORBUTT, D.

1972: “The New Sociology of Education," Education for Teaching, No. 89, 3-11.

HALL, S. and JEFFERSON, T., eds.

1976: Resistance through Rituals. London: Hutchinson.

HAMMERSLEY, M. and WOODS, P., eds.

1976: The Process of Schooling. London: Open University/ Routledge \& Kegan Paul.

HEBDIGE, D.

1979: Subculture: The Meaning of Style. London: Methuen. JOHNSON, R.

1976: "Notes on the Schooling of the English Working Class, 1780-1850," in Dale, R. et al., eds., Schooling and Capitalism. KEDDIE, N. London: Open University/Routledge \& Kegan Paul, 44-54.

1971: "Classroom Knowledge," in Young, M.F.D., ed., Knowledge and Control: New Directions for the Sociology of Education. London: Collier Macmillan, 133-60.

KEDDIE, N., ed.

1973: Tinker, Tailor... The Myth of Cultural Deprivation. Harmondsworth, Middlesex: Penguin Books.

KUHN, T.

1962: The Structure of Scientific Revolutions. Chicago: University of Chicago Press.

LANGER, S.K.

1960: Philosophy in a New Key. Cambridge, Mass.: Harvard University Press.

MARSLAND, D.

1982: "The Sociology of Adolescence and Youth," in Hartnett, A., ed., The Social Sciences in Educational Studies. London: Heinemann, 153-65.

MEYER, L.B.

1956: Emotion and Meaning in Music. Chicago: University of Chicago Press.

1959: "Some Remarks on Value and Greatness in Music," Journal of Aesthetics and Art Criticism, XVII/4, 486-500.

1973: Explaining Music. Berkeley: University of California Press.

NAVARRO, V.

1976: Medicine Under Capitalism. London: Croom Helm. NICHOLLS, M.

1980: "Running an 'Open' Music Department," in Vulliamy, G. and Lee, E., eds., Pop Music in School, rev. ed. London: Cambridge University Press, 123-40.

PARSONS, T.

1951: The Social System. New York: Free Press of Glencoe. 
PAYNTER, J.

1983: Music in the Secondary School Curriculum. London: PLEASANTS, $\mathrm{H}$. Cambridge University Press.

1969: Serious Music and all that Jazz. London: Gollancz. PRING, R.

1972: "Knowledge Out of Control," Education for Teaching, No. 89, 19-28.

RAINBOW, B.

1967: The Land Without Music. London: Novello.

SCHUTZ, A.

1971: "Making Music Together: A Study in Social Relationship," in Collected Papers II: Studies in Social Theory. The Hague: Martinus Nijhoff, 159-78.

SHARP, R. and GREEN, A.

1975: Education and Social Control: A Study in Progressive Primary Education. London: Routledge \& Kegan Paul.

SHEPHERD, J.

1977: "Media, Social Process and Music," "The 'Meaning' of Music," "The Musical Coding of Ideologies," in Shepherd, J. et al., Whose Music? A Sociology of Music Languages. London: Latimer New Dimensions; reprinted New Brunswick, N.J.: Transaction Books, 1980, 7-124.

1982: "A Theoretical Model for the Sociomusicological Analysis of Popular Music," Popular Music, No. 2, 145-77.

1983: "Conflict in Patterns of Socialization: The Role of the Classroom Music Teacher," The Canadian Review of Sociology and Anthropology, xx/1, 22-43.

SHEPHERD, J. and VULLIAMY, G.

1983: "A Comparative Sociology of School Knowledge," British Journal of Sociology of Education, IV/1, 3-18.

SINCLAIR, J. and COULTHARD, R.

1975: Towards an Analysis of Discourse. London: Oxford SPENDER, D. University Press.

1982: Invisible Women: The Schooling Scandal. London: Writers and Readers Publishing Cooperative.

STACEY, M. et al, eds.

1977: Health and the Division of Labour. London: Croom Helm. STANWORTH, M.

1983: Gender and Schooling: A Study of Sexual Divisions in the Classroom. London: Hutchinson.

SWANWICK, K.

1982: "Problems of a Sociological Approach to Pop Music: A Case Study," paper presented to the 15th International Society for Music Education Conference, Bristol, England; 
TANNER, J.

published in Dodds, J., ed., Tradition and Change in Music and Music Education. International Society for Music Education, 1983, pp. 136-41.

1981: "Pop Music and Peer Groups: A Study of Canadian High School Students' Response to Pop Music," The Canadian TAYLOR, L. Review of Sociology and Anthropology, xvII/1, 1-13.

1983: [Column-Laurie Taylor], The Times Higher Education Supplement, No. 548, May 6, [p. 32].

VULLIAMY, G.

1975: "Music Education: Some Critical Comments," Journal of Curriculum Studies, vil/1, 18-25.

1976: "What Counts as School Music?" in Whitty, G. and Young, M., eds., Explorations in the Politics of School Knowledge. Driffield: Nafferton Books, 19-34.

1977a: "Music and the Mass Culture Debate," in Shepherd, J. et al., Whose Music? A Sociology of Musical Languages. London: Latimer New Dimensions; reprinted New Brunswick, N.J.: Transaction Books, 1980, 179-200.

1977b: "Music as a Case Study in the 'New Sociology of Education'," in Shepherd, J. et al., Whose Music? A Sociology of Musical Languages. London: Latimer New Dimensions; reprinted New Brunswick, N.J.: Transaction Books, 1980, 201-32.

1978: "Culture Clash and School Music: A Sociological Analysis," in Barton, L. and Meighan, R., eds., Sociological Interpretations of Schooling and Classrooms: A Reappraisal. Driffield: Nafferton Books, 115-27.

1980a: "Definitions of Serious Music," in Vulliamy, G. and Lee, E., eds., Pop Music in School, rev. ed. London: Cambridge University Press, 33-48.

1980b: "Pupil-Centred Music Teaching," In Vulliamy, G. and Lee, E., eds., Pop Music in School, rev. ed. London: Cambridge University Press, 49-61.

VULLIAMY, G. and LEE, E.

1982a: "Black Studies," in Popular Music: A Teachers' Guide. London: Routledge \& Kegan Paul, 78-86.

VULLIAMY, G. and LEE, E., eds.

1982b: Pop, Rock and Ethnic Music in School. London: Cambridge University Press.

VULLIAMY, G. and SHEPHERD, J.

1984: Sociology and Music Education: A Response to Swanwick," British Journal of Sociology of Education, V/1, 57-76.

WADSWORTH, M. and ROBINSON, D., eds.

1976: Studies in Everyday Medical Life. London: Martin Robertson. 
WALKER, S. and BARTON, L., eds.

1983: Gender, Class and Education. Lewes: Falmer Press. WHITTY, G.

1974: "Sociology and the Problem of Radical Educational Change," in Flude, M. and Ahier, J., eds., Educability, Schools and Ideology. London: Croom Helm, 112-37.

1976: School Knowledge and Social Control (Course E202, Units 14-15). Milton Keynes: Open University Press.

WHITTY, G. and YOUNG, M., eds.

1976: Explorations in the Politics of School Knowledge. Driffield: Nafferton Books.

WISHART, T.

1977: "Musical Writing, Musical Speaking," in Shepherd, J. et al., Whose Music? A Sociology of Musical Languages. London: Latimer New Dimensions; reprinted New Brunswick, N.J.: Transaction Books, 1980, 125-53.

WRIGHT, D.F.

1975: "Musical Meaning and its Social Determinants," Sociology, IX/3, 419-35.

n.d.: "A Sociological Analysis of Two Music Classes," unpublished manuscript.

YOUNG, M.F.D., ed.

1971: Knowledge and Control: New Directions for the Sociology of Education. London: Collier Macmillan. 